\title{
HOPE-3 - „nowa nadzieja” dla polypill?
}

\author{
HOPE-3: truly a 'new hope' for polypill? \\ Barbara Uznańska-Loch, Jarosław D. Kasprzak \\ Klinika i Katedra Kardiologii Uniwersytetu Medycznego w Łodzi
}

\section{Streszczenie}

Opisano wyniki ważnego badania HOPE-3 (Heart Outcomes Prevention Evaluation), w którym testowano efekty leczenia stałą dawką leku hipolipemizującego (rosuwastatyna $10 \mathrm{mg}$ ) i połączenia kandesartanu i hydrochlorotiazidu o działaniu hipotensyjnym w grupie pacjentów cechujących się średnim ryzykiem sercowo-naczyniowym. Wyniki potwierdzają bezpieczeństwo i skuteczność obniżenia stężenia cholesterolu frakcji LDL statyną, a korzyści z terapii hipotensyjnej, zgodnie z oczekiwaniami, były zawężone do jedynie 1/3 pacjentów z wyższymi wartościami ciśnienia tętniczego.

Słowa kluczowe: farmakoterapia

Folia Cardiologica 2016; 11, 4: 359-362

\section{Wstęp}

Jednym z najważniejszych cykli w kardiologii prewencyjnej są badania HOPE (Heart Outcomes Prevention Evaluation). Poczynając od pierwszego HOPE, które zrewolucjonizowało prewencję wtórną powikłań krążeniowych, gdyż dowiedziono w nim korzyści ze stosowania ramiprilu [1], poprzez drugie z badań, w którym wykluczono celowość korekty stężenia homocysteiny przy użyciu suplementów kwasu foliowego i witamin z grupy B (HOPE-2) [2], do trzeciego (HOPE-3), przeprowadzonego pod kierownictwem Salima Yusufa w 228 ośrodkach z 21 krajów, którego wyniki ogłoszono niedawno [3]. Podstawowym celem tego badania była ocena możliwości obniżenia ryzyka powikłań krążeniowych u pacjentów z grupy pośredniego ryzyka przy użyciu stałej dawki leku hipotensyjnego oraz statyny, w dwuczynnikowym systemie randomizacji $2 \times 2$.

Podwyższone wartości skurczowego ciśnienia tętniczego (SBP, systolic blood pressure) oraz stężenia cholesterolu frakcji LDL (low-density lipoprotein) przekładają się na wzrastające ryzyko wystąpienia choroby układu sercowo-naczyniowego, a oba te czynniki razem odpowiadają za 2/3 ryzyka uwarunkowanego charakterystyką populacji. Dlatego potencjalnie jednoczesne działanie na oba czynniki ryzyka mogłoby przynieść lepszy rezultat niż leczenie ograniczone do jednego z nich. Wiadomo, że większość zdarzeń sercowo-naczyniowych (rozpatrując liczbę bezwzględną) zachodzi w licznej populacji osób cechujących się średnim ryzykiem, u których jest to pierwsza manifestacja problemu. Dlatego w ujęciu populacyjnym działania ukierunkowane na takie osoby mogłyby wyeliminować większą liczbę incydentów sercowo-naczyniowych niż leczenie wyłącznie osób obciążonych wysokim ryzykiem. Przedstawiane badanie wpisuje się w koncepcję wdrożenia do stosowania w populacji ogólnej polypill - stanowiącej połączenie stałej dawki różnych leków prewencyjnych uniwersalnej tabletki dla osób w średnim i starszym wieku.

Do badania HOPE-3 włączono 12705 osób cechujących się pośrednim ryzykiem rozumianym jako roczne ryzyko poważnych zdarzeń sercowo-naczyniowych na poziomie $1 \%$. Stosowano kryterium wieku 55 i więcej lat u mężczyzn oraz 65 i więcej lat u kobiet, jeśli występował jeden dodatkowy czynnik ryzyka; włączano również kobiety od 60. roku życia, jeżeli występowały u nich dwa dodatkowe czynniki ryzyka. Uwzględniono następujące czynniki ryzyka: podwyższony wskaźnik talia-biodra, niskie stężenie cholesterolu frakcji HDL (high-density lipoprotein), wywiad palenia tytoniu, zaburzenia gospodarki węglowodanowej, obciążenie ro- 
dzinne, niewielka niewydolność nerek. Średnia wieku wyniosła 65,7 roku, a 46,2\% uczestników stanowiły kobiety. Wykluczano osoby z potwierdzoną chorobą układu sercowo-naczyniowego, umiarkowaną lub ciężką niewydolnością nerek albo przeciwwskazaniami do zastosowania badanych leków. Nie ustalano żadnego wymaganego progu wartości ciśnienia ani stężenia cholesterolu.

W celu oceny tolerancji preparatów oraz współpracy badanego, osoby kwalifikowane do udziału w badaniu przez pierwsze 4 tygodnie otrzymywały aktywną terapię podwójną opisaną poniżej. Dopiero po tym okresie wstępnym następowało losowanie docelowej terapii długoterminowej, obejmującej:

- dwie tabletki placebo (podwójne placebo, $n=3168$ );

- tabletkę $10 \mathrm{mg}$ rosuwastatyny oraz tabletkę złożoną zawierającą $16 \mathrm{mg}$ kandesartanu i 12,5 mg hydrochlorotiazydu (aktywna terapia podwójna, $n=3180$ );

- tabletkę placebo oraz tabletkę złożoną zawierającą $16 \mathrm{mg}$ kandesartanu i 12,5 mg hydrochlorotiazydu (pojedyncza terapia przeciwnadciśnieniowa, $n=3176$ );

- tabletkę $10 \mathrm{mg}$ rosuwastatyny oraz tabletke placebo (pojedyncza terapia hipolipemizująca, $n=3181$ ).

Osoby z nadciśnieniem tętniczym przyjmujące leki $z$ innych grup niż stosowane $w$ badaniu także mogły być włączone. Jeżeli uczestnik badania otrzymał statynę od lekarza prowadzącego, to tabletkę rosuwastatyny lub jej placebo wycofywano.

W kilkuletniej obserwacji (mediana czasu trwania obserwacji wyniosła 5,6 roku) zaplanowano następujące dwa pierwszorzędowe punkty końcowe:

1) złożony punkt końcowy obejmujący zgon z przyczyn sercowo-naczyniowych, zawał serca, udar mózgu;

2) zdarzenia z punktu 1) oraz dodatkowo niewydolność serca, nagłe zatrzymanie krążenia, rewaskularyzacja wieńcowa.

Drugorzędowy punkt końcowy obejmował zdarzenia z punktu pierwszorzędowego 2) poszerzone o dławicę piersiową z udokumentowanym niedokrwieniem miokardium.

\section{Porównanie aktywnej terapii podwójnej z podwójnym placebo [4]}

Pierwszy pierwszorzędowy punkt końcowy wystąpił u 113 uczestników (3,6\%) w porównaniu ze 157 osobami (5\%), co oznacza względną redukcję ryzyka o $29 \%$ i bezwzględną o 1,4 punktu procentowego (hazard względny [HR, hazard ratio] 0,71, 95-procentowy przedział ufności [Cl, confidence interval] 0,56-0,9; $p=0,005)$. Natomiast drugi punkt końcowy wystąpił u 136 osób (4,3\%) w porównaniu ze 187 badanymi (5,9\%), zatem względna redukcja ryzyka wyniosła 28\%, a bezwzględna - o 1,6 punktu procentowego (HR $0,72,95 \% \mathrm{Cl} 0,57-0,89 ; p=0,003)$. Były też inne istotne różnice. Drugorzędowy punkt końcowymi wystąpił u 147 osób aktywnie leczonych (4,6\%) w porównaniu z 205 (6,5\%) otrzymującymi placebo (HR 0,71). Udar mózgu (wszystkich typów) stwierdzono u 31 (1\%) w porównaniu z 55 (1,7\%) osobami (HR 0,56). Zawał serca także występował rzadziej w grupie leczonej aktywnie - $21(0,7 \%)$ porównaniu z 38 $(1,2 \%)$ uczestnikami (HR 0,55). Nie zaobserwowano natomiast istotnego obniżenia ryzyka zgonu ogółem (163 v. 178) ani zgonów z przyczyn krążeniowych (75 v. 91).

Osłabienie mięśni oraz zawroty głowy były częstsze w grupie aktywnie leczonej, ale odwracalne po czasowym odstawieniu tabletek. Zanotowano jeden przypadek rabdomiolizy u osoby przyjmującej rosuwastatynę plus placebo. Ogólna częstość zaniechania przyjmowania tabletek była podobna. Po 2 latach w grupie aktywnej terapii podwójnej 83,6\% osób nadal przyjmowało obie tabletki, w grupie otrzymującej podwójne placebo - 83,3\%. Podobnie pod koniec badania odsetek ten wynosił $74,6 \%$ w porównaniu z $71,8 \%$.

\section{Aktywna terapia hipolipemizująca a placebo [5]}

W tych analizach zebrano dane z grupy aktywnego podwójnego i pojedynczego leczenia, zatem porównanie objęło 6361 osób otrzymujących rosuwastatynę w dawce $10 \mathrm{mg} /$ dobę oraz 6344 osób przyjmujących zamiast niej placebo. W całej populacji wyjściowo średnie stężenie cholesterolu całkowitego wynosiło 201,4 mg/dl, a cholesterolu frakcji LDL - 127,8 mg/dl. W grupie leczonej aktywnie uzyskano niższe niż w grupie otrzymującej placebo stężenie cholesterolu frakcji LDL, odpowiednio, o $39,6 \mathrm{mg} / \mathrm{dl}$ po roku, $34,7 \mathrm{mg} / \mathrm{dl}$ po 3 latach i $29,5 \mathrm{mg} / \mathrm{dl}$ na koniec badania. Zanotowano też istotnie niższe stężenia triglicerydów, apolipoproteiny B i białka C-reaktywnego oznaczanego metodą wysokoczułą (hsCRP, high-sensitivity C-reactive protein).

Pierwszy pierwszorzędowy punkt końcowy wystąpił u 235 uczestników otrzymujących statynę (3,7\%) w porównaniu z 304 osobami z grupy przyjmującej placebo $(4,8 \%)$; uzyskano względne obniżenie ryzyka o $24 \%$, czyli leczenie 91 osób zapobiegało jednemu powikłaniu. Drugi pierwszorzędowy punkt końcowy wystąpił u 277 (4,4\%) w porównaniu z 363 osobami (5,7\%), a względne zmniejszenie ryzyka wyniosło $25 \%$, zatem leczenie 73 osób zapobiegało wystąpieniu jednego zdarzenia. Drugorzędowy punkt końcowy wystąpił u 306 osób aktywnie leczonych $(4,8 \%)$ w porównaniu z 393 (6,2\%) otrzymującymi placebo (HR 0,77).

Udar mózgu (wszystkich typów) stwierdzano rzadziej w grupie otrzymującej statynę - u 70 (1,1\%) w porównaniu z 99 (1,6\%), co oznacza 30-procentowe zmniejszenie ryzyka. Zawał serca także występował rzadziej w grupie leczonej aktywnie - 45 (0,7\%) w porównaniu z 69 (1,1\%) uczestnikami, co oznacza 35-procentowe obniżenie ryzyka. Nie zaobserwowano znamiennego statystycznie zmniejszenia całkowitej liczby zgonów ogółem (334 v. 357) ani zgonów z przyczyn krążeniowych (154 v. 171). 


\section{Aktywna terapia przeciwnadciśnieniowa a placebo [6]}

W tych analizach zebrano dane z grupy aktywnego podwójnego i pojedynczego leczenia, zatem porównanie objęło 6356 osób otrzymujących kandesartan z hydrocholortiazydem w porównaniu z 6349 osobami otrzymującymi zamiast wyżej wymienionych leków placebo. W całej populacji ciśnienie tętnicze wynosiło średnio 138,1/81,9 mm Hg. Ciśnienie tętnicze miało wartość 138,2/82 mm Hg w grupach aktywnie leczonych przeciwnadciśnieniowo i 137,9/81,8 mm Hg w grupie przyjmującej placebo. Podczas obserwacji uzyskano jego obniżenie o, odpowiednio, 10/5,7 mm Hg i 4/2,7 mm Hg (aktywne leczenie przełożyło się zatem na dodatkowy spadek o 6/3 mm Hg).

Nie zanotowano istotnej różnicy w zakresie częstości wystąpienia pierwszorzędowych ani drugorzędowych punktów końcowych (uwzględniając drugi złożony drugorzędowy punkt końcowy - obniżenie ciśnienia tętniczego i udar mózgu). Natomiast korzyść z aktywnego leczenia zanotowano w podgrupie uczestników z SBP w najwyższej 1/3 zmierzonego zakresu. Wśród osób z SBP ponad 143,5 mm Hg (średnio 154 mm Hg) poddanych aktywnej terapii przeciwnadciśnieniowej w porównaniu z osobami otrzymującymi placebo rzadziej wystąpił pierwszorzędowy punkt końcowy pierwszy (HR 0,73) i drugi (HR 0,76), a także pierwszy z punktów drugorzędowych (HR 0,72).

\section{Wnioski z całego badania}

Opisywane badanie ma przełomowe znaczenie dla strategii pierwotnego zapobiegania powikłaniom krążeniowym w bardzo licznej populacji osób cechujących się średnim ryzykiem. Wykazano jednoznacznie korzyści ze stosowania małej dawki silnej statyny, zapewniającej obniżenie cholesterolu frakcji LDL poniżej progu $100 \mathrm{mg} /$ dl. Efekt dotyczył homogennie całej badanej grupy i potwierdza stosowana dotychczas regułę lower is better, wspierając europejskie podejście do terapii hipolipemizującej. Odmiennie ułożyły się korzyści z leczenia hipotensyjnego opartego na kandesartanie i tiazydzie. Tylko osoby z SBP w najwyższej $1 / 3$ zakresu (SBP > 143,5 mm Hg) odnosiły istotną korzyść z aktywnej terapii przeciwnadciśnieniowej. Włączanie leczenia przeciwnadciśnieniowego u osób cechujących się pośrednim ryzykiem sercowo-naczyniowym nie przynosi korzyści, jeśli SBP nie przekracza 140 mm Hg, co w pewien sposób potwierdza trafność obecnie stosowanej definicji nadciśnienia tętniczego. Nie jest znana odpowiedź na pytanie, jakie byłyby wyniki w przypadku terapii hipotensyjnej opartej na lekach silniej wpływających na zapobieganie chorobie wieńcowej (inhibitor konwertazy angiotensyny w połączeniu np. z antagonistą wapnia). Przedstawione wyniki potwierdzają jednak inny profil korzyści z aktywnej terapii hipolipemizującej, który - podobnie jak we wcześniejszych badaniach - był niezależny od wyjściowych wartości ciśnienia czy stężenia cholesterolu frakcji LDL. Opisane rezultaty stosowania podwójnej terapii aktywnej właściwie duplikują wnioski z analizy wpływu rosuwastatyny, która w dominującej mierze warunkowała korzystne efekty leczenia (z wyjątkiem pacjentów z nadciśnieniem tętniczym). Wprawdzie w opisanym czasie obserwacji nie wykazano znamiennego zmniejszenia śmiertelności, ale akumulacja powikłań w grupie przyjmującej placebo może spowodować, że takie dane się pojawią w wyniku wydłużonej obserwacji uczestników badania. Jak zatem odnieść wyniki HOPE-3 do promowanej przez prof. Salima Yusufa koncepcji polypill - uniwersalnej tabletki prewencyjnej do stosowania populacyjnego? Z pewnością potwierdza się dobre bezpieczeństwo współczesnych leków kandydatów oraz korzyści przynajmniej z komponenty hipolipemizującej. Określenie optymalnej populacji docelowej dla takiej koncepcji prewencji wymaga jednak dalszych badań.

\section{Konflikt interesów}

Autorzy deklarują brak konfliktu interesów.

\section{Abstract}

This report describes the outcomes of a significant trial HOPE-3 (Heart Outcomes Prevention Evaluation), which was testing the effects of fixed-dose therapy using a strong statin (rosuvastatin $10 \mathrm{mg}$ ) and a combination antihypertensive pill containing candesartan and hydrochlorothiazide in a large cohort of medium level cardiovascular risk individuals. The results confirm the safety and benefits from LDL-cholesterol lowering using a strong statin but hypotensive therapy was, expectedly, effective only in the top blood pressure tercile of the study participants.

Key words: pharmacotherapy

Folia Cardiologica 2016; 11, 4: 359-362 


\section{Piśmiennictwo}

1. Yusuf S., Sleight P., Pogue J. i wsp. Effects of an angiotensin-converting-enzyme inhibitor, ramipril, on cardiovascular events in high-risk patients. The Heart Outcomes Prevention Evaluation Study Investigators. N. Engl. J. Med. 2000; 342: 145-153.

2. Lonn E., Yusuf S., Arnold M.J. i wsp.; Heart Outcomes Prevention Evaluation (HOPE) 2 Investigators. Homocysteine lowering with folic acid and B vitamins in vascular disease. N. Engl. J. Med. 2006; 354: 1567-1577.

3. Lonn E., Bosch J., Pogue J. i wsp.; HOPE-3 Investigators. Novel approaches in primary cardiovascular disease prevention: the HOPE-3 trial rationale, design, and participants' baseline characteristics. Can. J. Cardiol. 2016; 32: 311-318.
4. Yusuf S., Lonn E., Pais P. i wsp.; HOPE-3 Investigators. Blood-pressure and cholesterol lowering in persons without cardiovascular disease. N. Engl. J. Med. 2016; 374: 2032-2043.

5. Yusuf S., Bosch J., Dagenais G. i wsp.; HOPE-3 Investigators. Cholesterol lowering in intermediate-risk persons without cardiovascular disease. N. Engl. J. Med. 2016; 374: 2021-2031.

6. Lonn E.M., Bosch J., López-Jaramillo P. i wsp.; HOPE-3 Investigators. Blood-pressure lowering in intermediate-risk persons without cardiovascular disease. N. Engl. J. Med. 2016; 374: 2009-2020. 